\title{
THE VARIATIONS OF THE SPECIFIC GRAVITY OF THE PLASMA OF THE BLOOD AND THE MEANS AVAILABLE FOR ALTERING IT
}

\author{
BY NORMAN S. MOORE AND HAROLD J. STEWART \\ With the Assistance of Yetta Porosowsky \\ (From the Hospital of The Rockefeller Institute for Medical Research, New York)
}

(Received for publication July 10, 1930)

The protein content of the plasma of the blood can be calculated from the observed value of the specific gravity of the plasma with sufficient exactness for certain clinical purposes. This correlation was shown by Moore and Van Slyke (1), who found that the relationship is expressed by the formula: Grams total protein per 100 cc. plasma equal $343(G-1.0070), G$ being the observed specific gravity. They included measurements of the protein content of the plasma of normal individuals which were in agreement with those published by Linder, Lundsgaard and Van Slyke (2) in 1924, and by Salvesen (3) in 1926. These observers (2) (3) also pubiished data showing that the plasma of individuals analyzed over a long period of time exhibits variations in the total protein content. That there are alterations in the direction of a decrease in the protein content of the plasma of the blood in pathological states has been shown by Linder, Lundsgaard and Van Slyke (2) and by Epstein (4) in nephritis, by Salvesen (5) in cirrhosis of the liver, in other diseases in which the liver is involved, in diabetes, in nephritis, and in anemia, and by others. Decreases both in specific gravity and in protein content of the plasma have been shown by Butterfield, Erdwurm and Braddock (6) to be present in nephritis with edema and by Moore and Van Slyke (1) in nephritis with edema, that is to say, in Bright's disease.

The physiological variations in the proteins of the plasma and the means by which they may be altered experimentally have not been extensively studied. Greene and Rowntree (7) in 1924 demonstrated that the protein content of serum decreased after forced administra- 
tion by mouth at half hour intervals of water to dogs in amounts equal to 5 per cent of the body weight. In experiments of 8 hours duration, amounts of water equal to 80 per cent of the initial weight of the animal were given. They also found that the amount of hemoglobin in the blood was reduced and that the decrease occurred most rapidly during the first 2 hours, but continued throughout the experiment; it was approximately 15 per cent. The total volume of circulating blood accordingly increased during the period of diminished hemoglobin concentration. Comparison of the refractive index and of the viscosity of the serum did not indicate alteration in the relative proportion of the serum proteins. Previous to this (1922), Lee, Carrier and Whipple (8) observed increase in the total plasma of the blood of dogs following ingestion of copious amounts of water.

In 1925, Cipriani and Moracchini (9) reported observations on the concentration of proteins in the serum of cardiac and of nephritic patients basing their measurements on the refractometric method. In 9 of 10 patients the protein content of the serum increased 7 to 15 per cent 4 hours after rising in the morning. Two normal individuals under similar conditions showed no change. No change was observed either in normal or in pathological cases during a control period of 4 hours in bed.

Recently, Thompson, Thompson and Dailey (10) published data which aid in interpreting the observations of Cipriani and Moracchini. They found that increase in protein content of the plasma of normal individuals took place while standing still, following a period of rest in the recumbent position. They observed also rise in the specific gravity of the plasma of the blood. It is unfortunately not possible to compare their data with those now being reported since unlike the technique employed by us oxalate was used as the anticoagulant, nor with those reported by Moore and Van Slyke (1) who used heparin.

Little information appears therefore to be at hand dealing with factors which influence the amount of protein in the plasma of the blood. Nor are there many studies on the methods which affect its specific gravity. For these reasons the present study was undertaken. Observations were made in the case of normal individuals, others in patients in hospital, and others, still, in dogs. 


\section{TECHNIQUE}

The technique employed for measuring the specific gravity of plasma of the blood was that described by Moore and Van Slyke (1). Samples of blood were drawn from an arm vein, care being exercised to prevent stasis. Heparin was used as the anticoagulant. Evaporation was prevented before, during and after centrifuging by stoppering the tubes. A small bottle was used to weight the plasma. To obtain the specific gravity of the plasma the weight of the volume of plasma was divided by the weight of the same volume of water, both being at the same temperature. This procedure was performed in duplicate and checked within one or two in the fourth place of decimals. The method of calibration of the bottles for water was that described by Moore and Van Slyke (1).

\section{OBSERVATIONS}

The effect of anticoagulants on the specific gravity of the plasma of the blood. Because of the extensive use of potassium oxalate as an anticoagulant, it was used for this purpose on 3 occasions in order to compare its effect with that of heparin. Although oxalated plasma shows deviations from the values obtained in the case of heparinized plasma, there was in these few instances no constant difference between them. It is obvious therefore that the formula of Moore and Van Slyke is not applicable to oxalated plasma. If a larger series had been compared it would perhaps have been possible to correct the values obtained in the case of oxalated blood by inserting a constant factor in that formula, or else to derive a new formula for use with oxalated plasma.

Constancy of the specific gravity of the plasma of normal individuals during long and short periods. Linder, Lundsgaard and Van Slyke (2), Govaerts (11) and more recently Moore and Van Slyke (1) have shown that when the protein content of blood is low, as it is in certain cases of degenerative Bright's disease, it remains low over a long period of time and returns to a normal level slowly. Moore and Van Slyke (1) showed that the specific gravity of the plasma follows a parallel curve of recovery. We repeated these observations concerning the specific gravity of the plasma in 2 normal individuals on 3 successive days and on 4 successive days in a third. The blood was drawn at the same time each day with one exception when there was a delay of 15 minutes. 
In this case although the food taken at breakfast differed, the specific gravity maintained a constant level. The greatest variation in any individual was 0.0003 .

In patients suffering from cardiac disease, all in water equilibrium, blood was drawn at the same time each day in 5 cases. In each instance the level of the specific gravity remained constant. The greatest variation observed was 0.0004 . The specific gravity of the plasma and by inference therefore its protein content remains remarkably constant.

We have found, as have others (Linder, Lundsgaard and Van Slyke (2), Salvesen (3)), that the specific gravity of the plasma of normal individuals changes appreciably over long periods of time. In one individual the plasma proteins ${ }^{1}$ increased 0.5 gram per $100 \mathrm{cc}$. of plasma and in corresponding fashion the plasma specific gravity 0.0015 in a period of 14 months. In the case of a second normal subject, the specific gravity of the plasma increased 0.0011 during this time; whether a corresponding change in the total protein content occurred is not known.

On one subject the specific gravity was estimated 3 times during one day. In the middle of the day it was 0.0006 less than in the morning, or in the evening. It may therefore show slight fluctuations in a normal individual in the course of a day.

Comparison of the specific gravity and protein content of the plasma in arterial with that in venous blood. When the specific gravity of the plasma of arterial and of venous blood, taken at the same time, was estimated, as we had opportunity to do in 7 cases, that of venous blood was uniformly greater. The difference varied between 0.0006 and 0.0015 (table 1) and averaged 0.0010 . In one instance in addition to specific gravity estimations the protein content, obtained by chemical analysis (Case 1), was found to be greater in venous blood, the difference corresponding to that observed in the specific gravity. The application of a tourniquet was not responsible for the difference, for in Case 4 (table 1) blood was drawn without the use of one. The number of red blood cells, the oxygen capacity of the blood (hemo-

${ }^{1}$ The proteins in the plasma were separated into albumin and globulin fractions by Howe's method (12) and determined by Van Slyke's gasometric microKjeldahl procedure (13). 
globin content), and the percentage of red blood cells to plasma were all slightly greater in venous than in arterial blood (Case 5); arterial blood appears in short to be more dilute than venous blood.

TABLE 1

Difference in specific gravity and protein content of the plasma of arterial and of venous blood drawn from the median cubital vein of the arm

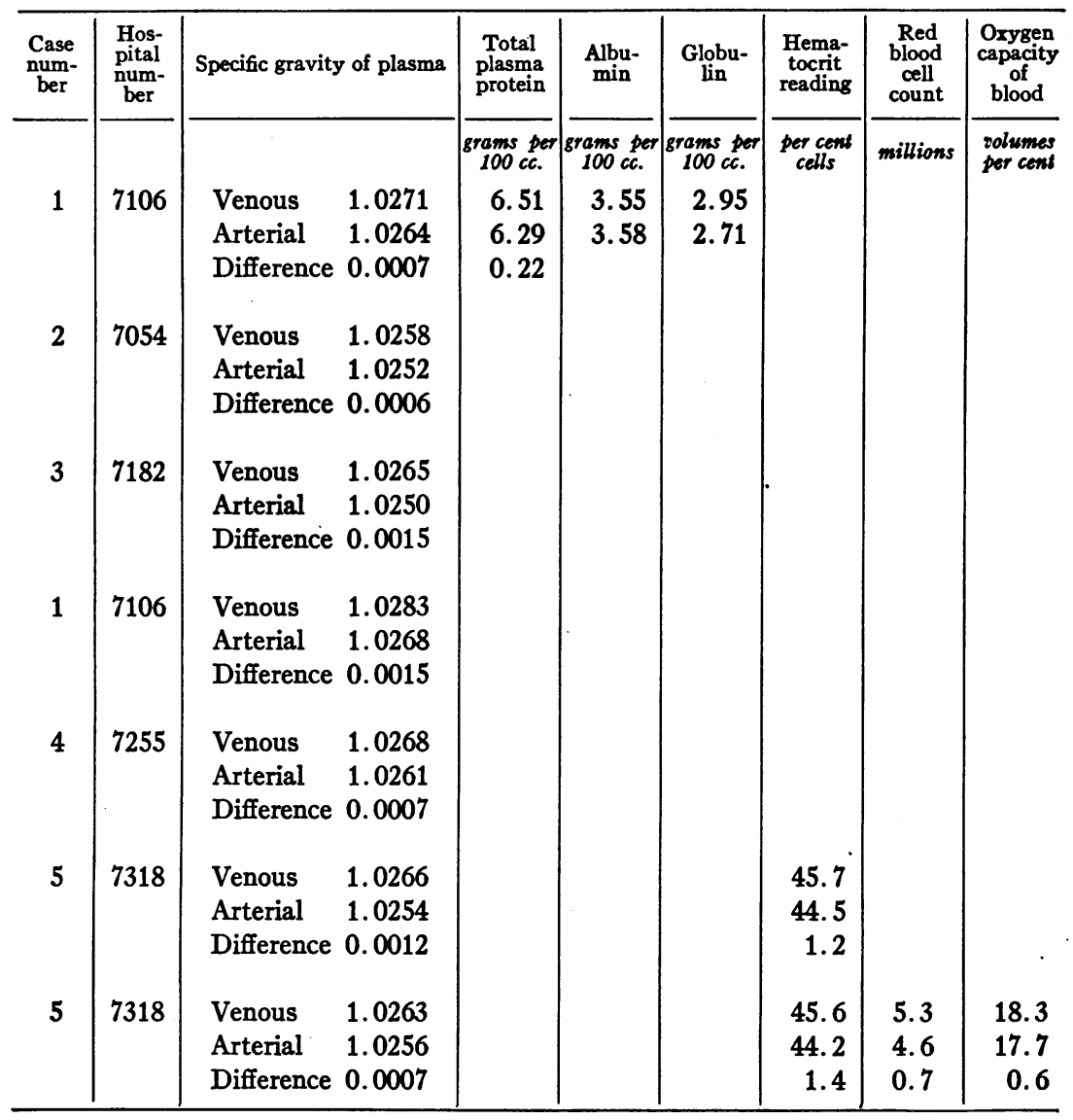

The effect of the injection of salt solution intravenously upon the specific gravity of the plasma of the blood. The effect of diluting the blood by the intravenous infusion of physiologic sodium chloride solution is shown in experiments in dogs in which an amount of fluid was injected which varied between 40 and 80 per cent of the total blood volume 
(table 2). In the first instance $(\operatorname{dog} 1)$, fifteen minutes after the infusion of $500 \mathrm{cc}$. having a specific gravity of 1.0052 , the specific gravity of the plasma fell 0.0015 from 1.0238 to 1.0223 . After 30 minutes a second infusion of $500 \mathrm{cc}$. was given. Fifteen minutes afterward the specific gravity of the plasma had fallen 0.0005 to 1.0218 , a total of 0.0020 lower than before the experiment began. The following day, the specific gravity was still low, but had returned to the ante-infusion

TABLE 2

Effect on specific gravity of the plasma of the blood of injecting intravenously into dogs normal salt solution

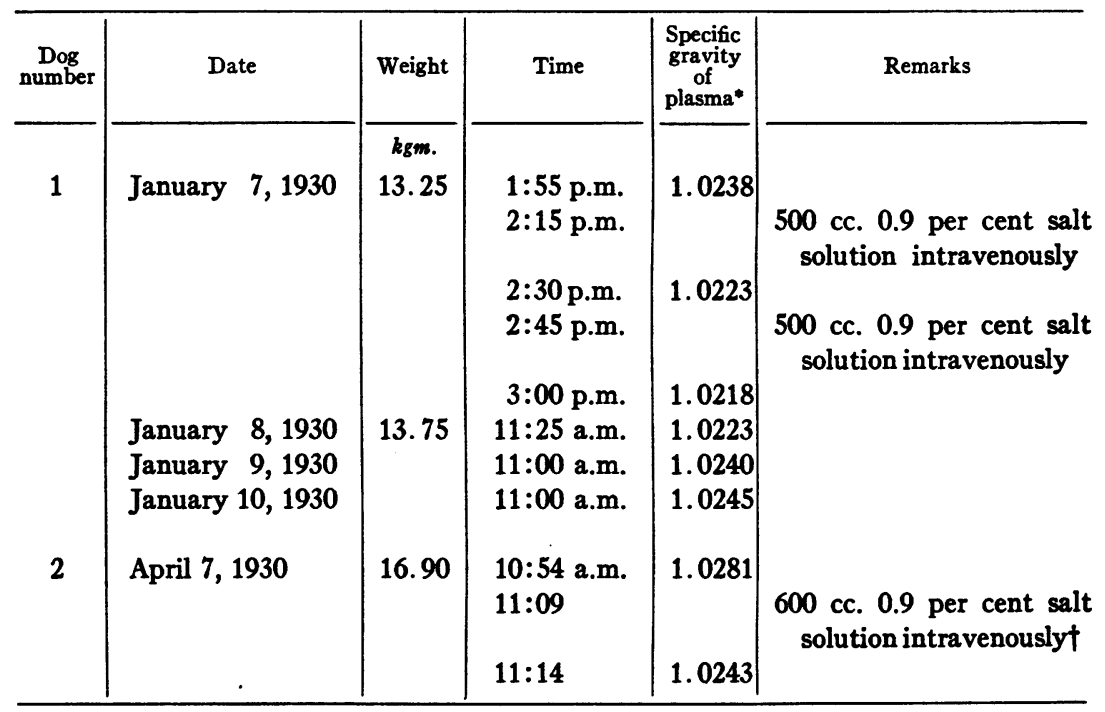

* Samples of blood were taken from a femoral artery since this was easier than drawing samples of venous blood.

$\dagger$ The specific gravity of this solution was 1.0055 .

level on the next day, and two days later remarkable to relate was higher still.

In the case of the second $\operatorname{dog}(\operatorname{dog} 2)$ the injection of $600 \mathrm{cc}$. of physiologic salt solution intravenously resulted in a decrease in the specific gravity of the plasma from 1.0281 to 1.0243 . In this instance a shorter time ( 5 minutes) elapsed between injection and taking the second sample of blood and presumably less of the fluid which was injected had passed out of the blood stream. This experiment demon- 
strates more accurately the degree of dilution of the blood which takes place after injection of salt solution than does the first.

Effect of hemorrhage on the specific gravity of the plasma. It has long been known that protein becomes deficient in the plasma of

TABLE 3 .

Effect of bleeding on the specific gravity of the plasma of the blood of dog 3

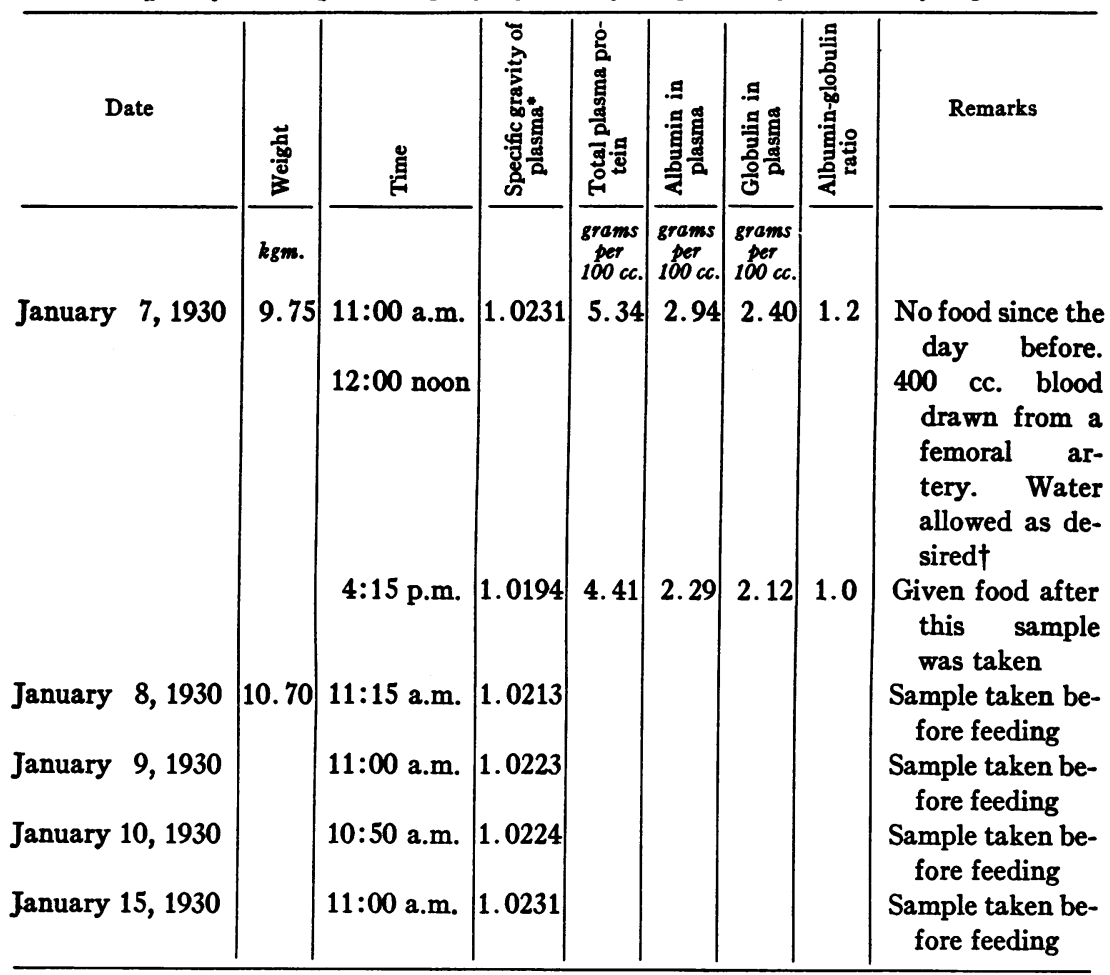

* Blood was drawn from a femoral artery since it was easier than taking samples of venous blood.

† This dog presumably had a total blood volume of approximately $1000 \mathrm{cc}$. Removing $400 \mathrm{cc}$. of blood therefore reduced the total blood volume to approximately 60 per cent of its initial value.

the blood on repeated bleeding (14). As a result of this procedure Leiter and McLean (15) showed that edema takes place in dogs although the washed corpuscles were returned to the blood stream. Later, when the proteins were again at normal concentration in the 
blood edema disappeared. When $400 \mathrm{cc}$. of blood were withdrawn from a dog, the total blood volume of which was approximately $1000 \mathrm{cc}$, the specific gravity fell 0.0037 at the end of 3 hours, from 1.0231 to 1.0194 (table 3). A period of 4 days was required for the return of the specific gravity to the original level. The total protein content estimated by chemical analysis fell from 5.34 grams per $100 \mathrm{cc}$. to 4.41 grams per $100 \mathrm{cc}$., an effect in agreement with that in specific gravity.

Effect of injecting hypertonic glucose solution intravenously on the specific gravity of the plasma of the blood. The idea has been current that hypertonic solutions of glucose when injected intravenously increase the osmotic pressure of the plasma of the blood (16), (17) since they draw water from the tissues of the body into the blood stream. That this actually occurs has been shown by Smith (18), who demonstrated that the volume of the plasma increased following the intravenous injection of glucose. At the height of the effect, dilution of the constituents of the blood, including the proteins, should occur and in consequence reduction in specific gravity of the plasma. We injected accordingly intravenously into dogs on two occasions $55 \mathrm{cc}$. and on a third $75 \mathrm{cc}$. of 50 per cent solution of glucose. Samples of blood were taken before injection and at intervals afterward. On the first occasion ( $\log 4)$, the specific gravity decreased 0.0021 within 6 minutes after injection and was returning $1 \frac{2}{3}$ and 4 hours later to the original level (table 4). In the case of dog 5 the specific gravity of the plasma fell 0.0024 from 1.0272 to 1.0248 within 5 minutes after injection of $55 \mathrm{cc}$. It exceeded the original level about 5 hours later. In the case of both dogs the decrease in specific gravity resulted presumably from the entrance of fluid into the blood stream. In the case of the third $\operatorname{dog}(\operatorname{dog} 6), 75 \mathrm{cc}$. were injected intravenously. The fall in specific gravity was only 0.0008 . It is probable in this instance that the large amount of glucose solution of high specific gravity (1.1811) counter-balanced the dilution effect of the water drawn in from the tissues. But in any case it appears that the intravenous injection of hypertonic solutions of glucose results in decrease in specific gravity of the plasma of the blood.

Effect of the ingestion of water 1000 cc. on the specific gravity of the plasma of the blood. Observations were made in two patients to 
whom $1000 \mathrm{cc}$. of water were given by mouth. The procedure as applied by Stewart and McIntosh (19) is briefly as follows: It is carried out in the morning. The patient receives no fluid after midnight. A specimen of urine collected at 6 a.m. is discarded. After voiding at 7 a.m. (this specimen is saved) the patient drinks $1000 \mathrm{cc}$. of water.

TABLE 4

Effect on the specific gravity of the plasma of the blood of injecting intravenously into dogs hypertonic solutions of glucose

\begin{tabular}{|c|c|c|c|c|}
\hline Dog number & Weight & Time & $\begin{array}{l}\text { Specific } \\
\text { gravity of } \\
\text { plasma* }\end{array}$ & Remarks \\
\hline 4 & $\begin{array}{l}\text { kgm. } \\
20.00\end{array}$ & $\begin{array}{l}\text { 9:57 a.m. } \\
\text { 10:00 a.m. } \\
\text { 10:06 a.m. } \\
\text { 11:47 a.m. } \\
\text { 3:30 p.m. }\end{array}$ & $\begin{array}{l}1.0261 \\
1.0240 \\
1.0248 \\
1.0252\end{array}$ & $\begin{array}{l}55 \text { cc. } 50 \text { per cent glucose solution } \\
\text { intravenously }\end{array}$ \\
\hline 5 & 18.75 & $\begin{array}{l}10: 32 \text { a.m. } \\
\text { 10:36 a.m. } \\
\text { 10:41 a.m. } \\
12: 20 \text { p.m. } \\
\text { 3:45 p.m. }\end{array}$ & $\begin{array}{l}1.0272 \\
1.0248 \\
1.0264 \\
1.0276\end{array}$ & $\begin{array}{l}55 \text { cc. } 50 \text { per cent glucose solution } \dagger \\
\text { intravenously }\end{array}$ \\
\hline 6 & 20.00 & $\begin{array}{l}10: 45 \text { a.m. } \\
10: 50 \text { a.m. } \\
\text { 10:57 a.m. } \\
12: 17 \text { p.m. } \\
\text { 3:00 p.m. }\end{array}$ & $\begin{array}{l}1.0279 \\
1.0271 \\
1.0274 \\
1.0274\end{array}$ & $\begin{array}{l}75 \text { cc. } 50 \text { per cent glucose solution } \\
\text { intravenously }\end{array}$ \\
\hline
\end{tabular}

* Samples of blood were drawn from a femoral artery by puncture, since this procedure was easier than taking samples of venous blood.

† Specific gravity of the glucose solution by the same method as that used in estimating the specific gravity of the plasma was 1.1811 .

No more fluid and no food are given until after the procedure is ended at 11 a.m. Specimens are collected at 8 , at 9 , at 10 and at 11 a.m. and are saved separately. They are measured and the specific gravity estimated. Normal individuals excrete all or nearly all of the $1000 \mathrm{cc}$. of water ingested within 4 hours; the specific gravity falls to 1.001 .

In the patients now studied samples of blood were taken immediately 
after each voiding and the specific gravity of the plasma was estimated. In the first instance (Case 3 ) the specific gravity decreased 0.0002 from 1.0260 to 1.0258 (table 5) and in the second instance (Case 1), it fell 0.0003 from 1.0271 to 1.0269 . In both instances the changes were small and may not be significant. Yet the lowest specific gravity of the plasma occurred at the time of the lowest specific gravity of the urine. The difference in the magnitude of the results between our observations and those in the animals of Greene and Rowntree is due,

TABLE 5

Effect on specific gravity of the plasma of the blood of ingestion of $1000 \mathrm{cc}$. of water (dilution test)

\begin{tabular}{|c|c|c|c|c|c|c|c|}
\hline $\begin{array}{c}\text { Case } \\
\text { number }\end{array}$ & $\begin{array}{l}\text { Hospital } \\
\text { number }\end{array}$ & Time & $\begin{array}{l}\text { Amount } \\
\text { of urine }\end{array}$ & $\begin{array}{l}\text { Specific } \\
\text { gravity of } \\
\text { urine }\end{array}$ & $\begin{array}{c}\text { Specific } \\
\text { gravity of } \\
\text { plasma }\end{array}$ & $\begin{array}{c}\text { Decrease } \\
\text { in specific } \\
\text { gravity } \\
\text { of plasma }\end{array}$ & Remarks \\
\hline 3 & 7182 & $\begin{array}{l}\text { 7:00 a.m. } \\
\text { 7:05 a.m. } \\
\text { 8:00 a.m. } \\
\text { 9:00 a.m. } \\
\text { 10:00 a.m. } \\
\text { 11:00 a.m. }\end{array}$ & $\begin{array}{r}c c . \\
35 \\
\\
55 \\
485 \\
175 \\
88\end{array}$ & $\begin{array}{l}1.022 \\
1.017 \\
1.002 \\
1.005 \\
1.011\end{array}$ & $\begin{array}{l}1.0260 \\
1.0263 \\
1.0258 \\
1.0259 \\
1.0262\end{array}$ & 0.0002 & 1000 cc. water \\
\hline 1 & 7106 & $\begin{array}{c}\text { 7:00 a.m. } \\
\text { 7:05 a.m. } \\
\text { 8:00 a.m. . } \\
\text { 9:00 a.m. } \\
\text { 10:00 a.m. } \\
\text { 11:00 a.m. } \\
\text { 12:00 noon }\end{array}$ & $\begin{array}{l}420 \\
\\
140 \\
102 \\
145 \\
154 \\
560\end{array}$ & $\begin{array}{l}1.020 \\
1.012 \\
1.002 \\
1.004 \\
1.006 \\
1.006\end{array}$ & $\begin{array}{l}1.0271 \\
1.0271 \\
1.0268 \\
1.0271 \\
1.0273 \\
1.0269\end{array}$ & 0.0003 & 1000 cc. water \\
\hline
\end{tabular}

no doubt, to the fact that in their animals water was given to the point of intoxication. On the other hand we are unable to account for the difference in results between our observations and those reported by Strasser (20), for in certain instances he observed definite increase in the specific gravity of the plasma following the ingestion of $1000 \mathrm{cc}$. of water.

Effect of withholding fluid and giving a dry diet upon the specific gravity of the plasma of the blood. Observations were made in two patients during procedures which have as their object the secretion by the kidneys of urine of high specific gravity. The procedure as applied by 
Stewart and McIntosh (19) is as follows: The patients are given 3 dry meals. Each meal consists of bread (toasted) 65 grams, butter 15 grams, eggs (scrambled) 100 grams, cream cheese 25 grams, and jam or jelly 15 to 20 grams. The caloric value of this meal is 600 calories, a total of 1800 calories. No water is given from midnight of the day preceding the procedure until its end. On the morning of the procedure the patient voids at $6 \mathrm{a} . \mathrm{m}$. This specimen is discarded. He voids at 7 a.m., this specimen is saved. The dry meals are given at 7.30,10.00 and 11.40 a.m. The patient voids at 9 and 11 a.m., and at

TABLE 6

Effect of withholding fluid and giving a dry diet on the specific gravity of the plasma of the blood

\begin{tabular}{|c|c|c|c|c|c|c|c|c|c|c|}
\hline $\begin{array}{c}\text { Case } \\
\text { number }\end{array}$ & $\begin{array}{l}\text { Hospital } \\
\text { number }\end{array}$ & Time & $\begin{array}{c}\text { Amount } \\
\text { of } \\
\text { urine }\end{array}$ & $\begin{array}{l}\text { Specific } \\
\text { gravity } \\
\text { of urine }\end{array}$ & $\begin{array}{l}\text { Specific } \\
\text { gravity } \\
\text { of } \\
\text { plasma }\end{array}$ & $\begin{array}{l}\text { Increase } \\
\text { in specific } \\
\text { gravity of } \\
\text { plasma }\end{array}$ & $\begin{array}{l}\text { Total } \\
\text { plasma } \\
\text { protein }\end{array}$ & $\begin{array}{l}\text { Plasma } \\
\text { albumin }\end{array}$ & $\begin{array}{c}\begin{array}{c}\text { Plasma } \\
\text { globulin }\end{array} \\
\text { a }\end{array}$ & $\begin{array}{c}\text { A/G } \\
\text { ratio }\end{array}$ \\
\hline \multirow{6}{*}{3} & \multirow{6}{*}{7182} & & $c c$. & & & \multirow{11}{*}{0.0013} & $\begin{array}{c}\text { grams } \\
\text { per } \\
100 \text { cc. }\end{array}$ & $\begin{array}{c}\text { grams } \\
\text { per } \\
100 \text { cc. }\end{array}$ & $\begin{array}{c}\text { grams } \\
\text { per } \\
100 \text { cc. }\end{array}$ & \multirow{4}{*}{1.7} \\
\hline & & 7 a.m. & 50 & 1.014 & 1.0259 & & \multirow{3}{*}{6.56} & \multirow{3}{*}{4.21} & \multirow{3}{*}{2.35} & \\
\hline & & 9 a.m. & 52 & 1.019 & 1.0269 & & & & & \\
\hline & & 11 a.m. & 80 & 1.020 & 1.0271 & & & & & \\
\hline & & 1 p.m. & 77 & 1.024 & 1.0272 & & 6.73 & 4.07 & 2.66 & 1.5 \\
\hline & & 3 p.m. & 84 & 1.025 & 1.0270 & & & & & \\
\hline \multirow[t]{5}{*}{1} & \multirow[t]{5}{*}{7106} & 7 a.m. & 90 & 1.018 & 1.0273 & & & & & \\
\hline & & 9 a.m. & 48 & 1.020 & 1.0276 & & & & & \\
\hline & & 11 a.m. & 75 & 1.023 & 1.0278 & & & & & \\
\hline & & 1 p.m. & 156 & 1.020 & 1.0286 & & & & & \\
\hline & & 3 p.m. & 246 & 1.024 & 1.0283 & & & & & \\
\hline
\end{tabular}

1 and 3 p.m.; each specimen is saved separately. The procedure ends after the specimen is collected at 3 p.m. The amount and specific gravity of each specimen are estimated. In normal individuals the specific gravity of the urine rises to 1.030 .

In these patients samples of blood were taken immediately after each voiding and specific gravity of the plasma estimated. In the first instance (Case 3) the specific gravity rose 0.0013 from 1.0259 to 1.0272 (table 6). There was a corresponding rise of 0.17 gram per $100 \mathrm{cc}$. in the total protein content of the plasma from 6.56 grams per $100 \mathrm{cc}$. to 6.73 grams per $100 \mathrm{cc}$. In the case of the second patient 
(Case 1) the specific gravity of the plasma rose 0.0013 from 1.0273 to 1.0286.

In two patients therefore, significant increases occurred in the specific gravity of the plasma due to increase in the concentration of plasma proteins dependent on the loss of fluid from the blood, when the patients were given a dry diet. It is not possible to compare the results of our observations with those reported by Strasser (20) since the procedures and times at which the samples of blood were drawn are not identical. In certain instances, however, he likewise observed increase in the specific gravity of the plasma.

TABLE 7

Effect of ingestion of fat on the specific gravity of the plasma of the blood

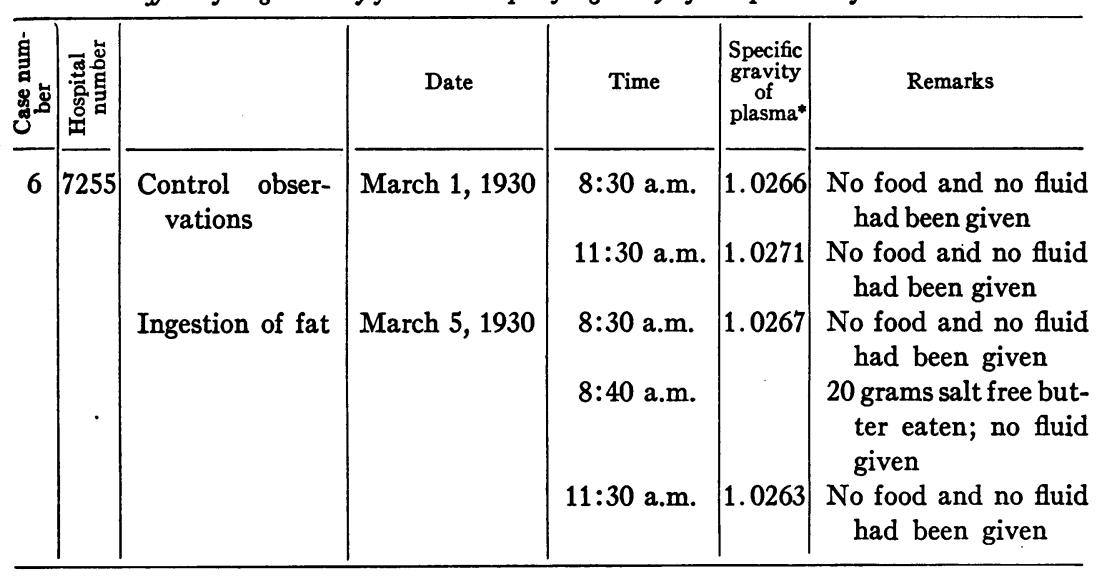

* The blood in each instance was drawn without stasis.

Effect of the ingestion of fat on the specific gravity of the plasma of the blood. Gage and Fish (21) demonstrated the presence of fat globules (chylomicrons) in the blood of human beings after the ingestion of fat. The maximum number of chylomicrons was found 3 to 4 hours after ingestion of fat by dark field illumination. It seemed that if sufficient fat were present in the blood the specific gravity of the plasma should reflect this situation by showing a decrease. To test this view the following observations were made. The subject was given no breakfast; a sample of blood was taken without stasis at 8.30 a.m. The specific gravity of the plasma was 1.0267 (table 7). The subject 
then ate salt free butter 20 grams; 3 hours later, no food and no fluid having been allowed during this time, a second sample of blood was taken; the specific gravity of the plasma fell 0.0004 to 1.0263 . When samples of blood were taken under exactly similar conditions, except that no fat was eaten, the specific gravity of the plasma increased 0.0005 from 1.0266 to 1.0271 . The ingestion of fat therefore was followed by decrease in specific gravity of the plasma although under control conditions increase in specific gravity occurred.

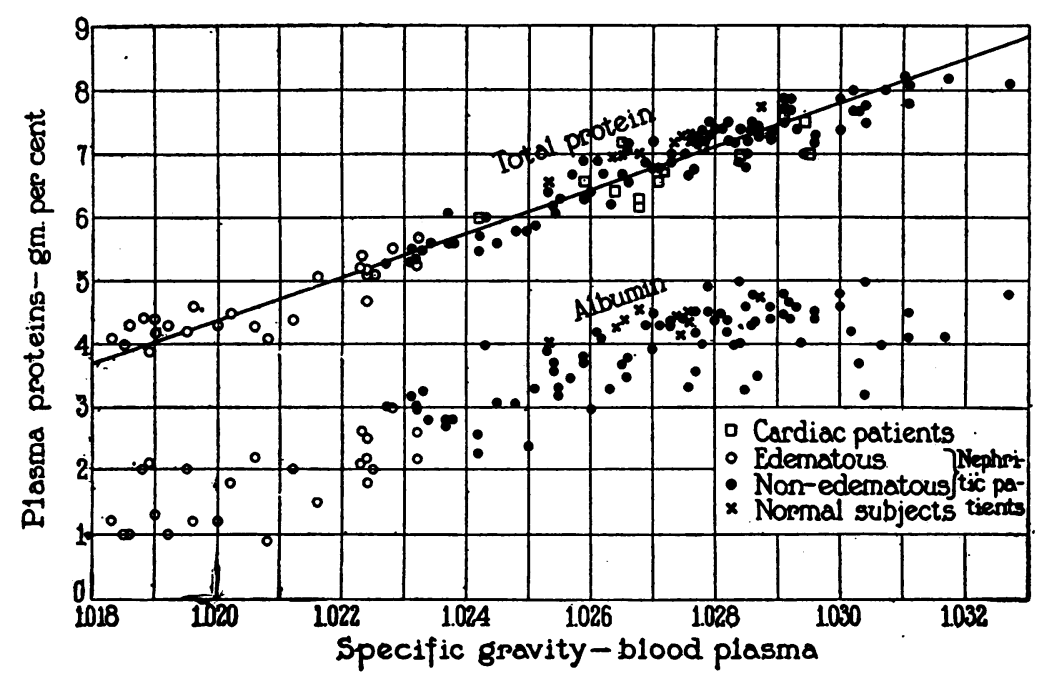

Fig. 1. Relationship of Piasma Specific Gravity to Plasma Protein Content in Normal Individuals and in Nephritic and Cardiac Patients

The data obtained for cardiac patients are plotted on the chart for normal individuals and nephritic patients in Moore and Van Slyke's paper (figure 3).

\section{Effect of injecting intravenously gum acacia dissolved in hypertonic} glucose solution on the specific gravity of the plasma of the blood in a patient exhibiting edema due to nephrosis. A patient who for 8 months had exhibited edema and generalized anasarca due to degenerative Bright's disease and in whom the plasma proteins were diminished during the presence of edema, was given by Van Slyke and Moore $450 \mathrm{cc}$. of 6 per cent solution of gum acacia in 20 per cent glucose solution in an attempt to raise the specific gravity above the zone characteristic of edema (fig. 1). The specific gravity before the first in- 
TABLE 8

Effect on the specific gravity of the plasma of the blood of injecting intravenously gum acacia into a patient exhibiting edema due to nephrosis

\begin{tabular}{|c|c|c|c|c|c|c|c|}
\hline $\begin{array}{c}\text { Case } \\
\text { number }\end{array}$ & $\left|\begin{array}{c}\text { Hospital } \\
\text { number }\end{array}\right|$ & Date & $\begin{array}{c}\text { Specific } \\
\text { gravity of } \\
\text { plasma }\end{array}$ & $\begin{array}{l}\text { Total } \\
\text { plasma } \\
\text { protein }\end{array}$ & $\begin{array}{l}\text { Albumin } \\
\text { in plasma }\end{array}$ & $\begin{array}{c}\text { Globulin } \\
\text { in plasma }\end{array}$ & Remarks \\
\hline 7 & 6644 & $\begin{array}{l}\text { April 19, } 1929 \\
\text { May 3, } 1929\end{array}$ & $\begin{array}{l} \\
1.0196 \\
1.0199 \\
1.0187 \\
1.0196\end{array}$ & $\begin{array}{c}\text { grams per } \\
100 \text { cc. } \\
4.6 \\
3.6 \\
3.8 \\
3.4\end{array}$ & $\begin{array}{c}\text { grams per } \\
100 \text { cc. } \\
1.3 \\
1.0 \\
1.2 \\
1.0\end{array}$ & $\begin{array}{c}\text { grams per } \\
100 \text { cc. } \\
3.3 \\
2.6 \\
2.6 \\
2.4\end{array}$ & $\begin{array}{l}\text { Before injection } \\
\text { After injection } \\
\text { Before injection } \\
\text { After injection }\end{array}$ \\
\hline
\end{tabular}

TABLE 9

Specific gravity and protein content of the plasma of cardiac patients

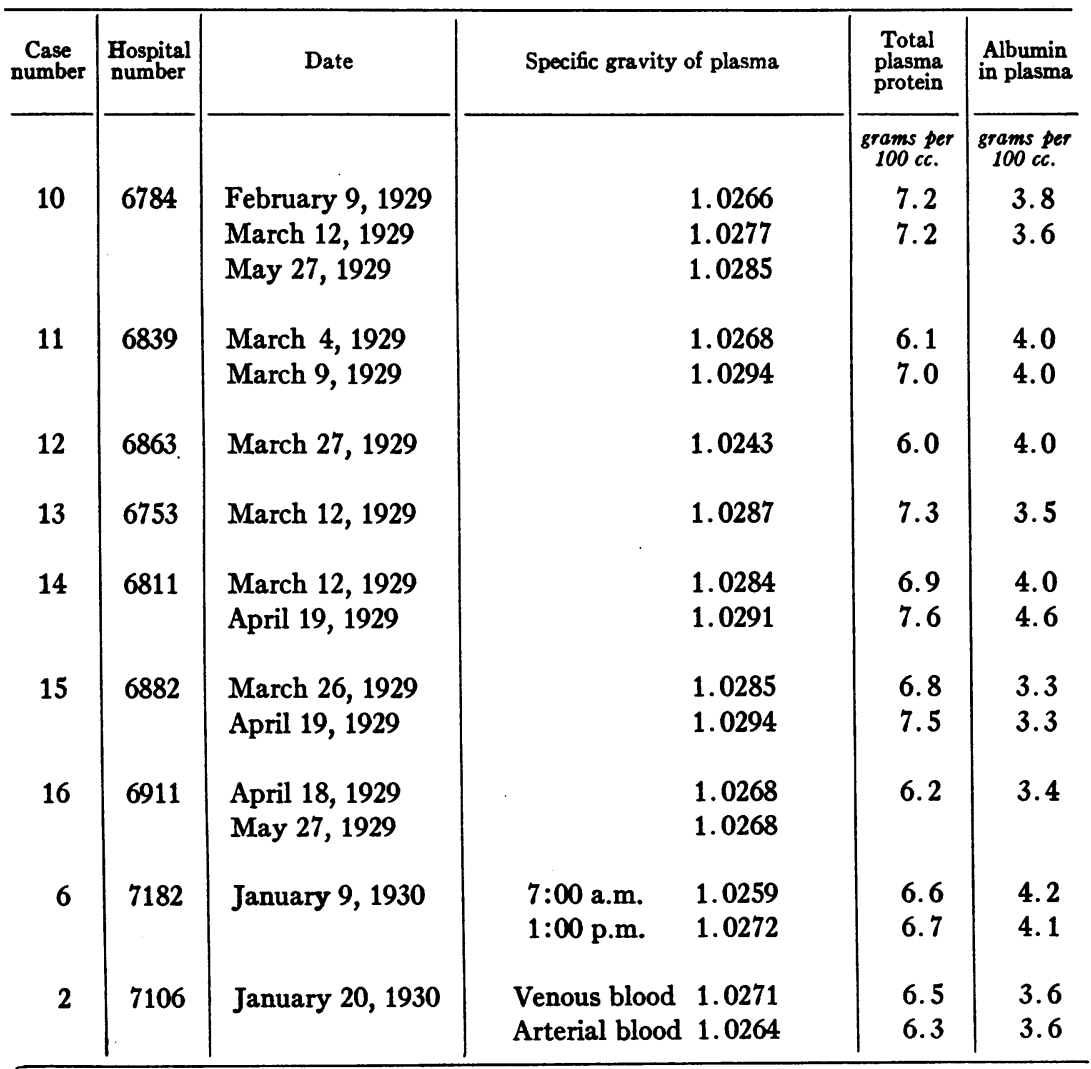


jection was 1.0196 and the total protein 4.6 grams per cent (table 8). As soon as the infusion was finished the specific gravity of the plasma rose to 1.0199 , but the total protein content of the plasma decreased to 3.6 grams per cent. Two weeks later the injection of $500 \mathrm{cc}$. of a similar solution resulted in similar changes. The increase in specific gravity was due presumably to the presence of gum acacia; the fall in the concentration of protein is explained partly by dilution of the plasma resulting from the volume of solution injected and partly by the entrance of fluid into the blood stream due to presence there of the hypertonic glucose solution (18).

Correlation in cardiac patients of the protein content and of the specific gravity of the plasma of the blood. Moore and Van Slyke (1) demonstrated a close agreement between the specific gravity of the plasma and protein content in normal individuals and in patients suffering from Bright's disease (hemorrhagic, degenerative and arteriosclerotic) whether edema was or was not present. In a corresponding fashion we have measured the protein content and the specific gravity of the plasma of a number of cardiac patients both those exhibiting edema as well as those free of it. The specific gravity of the plasma and the plasma protein content were both within the normal range (table 9). A correlation as in nephritic patients was found between the specific gravity and the protein content. If these data are inserted in figure 3 of Moore and Van Slyke's paper (1) now reproduced as figure 1, the points lie about the straight line drawn by them. In calculating the plasma protein content from the observed specific gravity their formula may therefore be used, in which plasma protein expressed in grams per $100 \mathrm{cc}$. of plasma equals $343(G-1.0070)$, where $G$ is the observed specific gravity.

\section{DISCUSSION}

We have presented data which show striking constancy in the specific gravity of the plasma of the blood in normal individuals as well as in the plasma proteins. We have also presented the results of our attempts to alter the specific gravity of the plasma.

That the specific gravity of the plasma and correspondingly of the concentration of proteins in the plasma vary within such small limits $(0.0003)$ in normal individuals and in cardiac patients $(0.0004)$ is sur- 
prising. Other observers (Linder, Lundsgaard and Van Slyke (2), Salvesen (3)) have called attention to variations which occur in the protein content of the plasma over long periods of time. We have confirmed these observations and have found in addition that changes in the specific gravity parallel changes in the concentration of plasma protein. During the course of a day the specific gravity was found to vary 0.0007 in one individual, being lowest in the middle of the day. How much variation, and presumably it is very little, is due to changes in water balance and how much to concentration of the blood due to standing and walking is not known. Thompson, Thompson and Dailey (10) believed that increase in the concentration of protein and increase in specific gravity of the plasma occur when the position of the body is changed from recumbent to standing, due to loss of fluid (approximately protein free) from the blood amounting on the average to 11 per cent of the total plasma volume. Their studies were based on estimations of blood volume. Cipriani and Moracchini (9) likewise observed increase in serum protein concentration in cardiac and nephritic patients 4 hours after rising, but observed no change in normal individuals. They employed the refractometric method. It may be recalled that Linder, Lundsgaard and Van Slyke (2) compared the results obtained by the refractometric method for the estimation of protein with those gained from chemical analysis of the blood by the Kjeldahl method and found that they differed as much as 1.5 gram of protein per $100 \mathrm{cc}$. of plasma in normal individuals.

The procedures which we have used to alter the concentration of protein and the specific gravity of the plasma have had as their basis dilution or concentration of the circulating blood by changing its fluid content; they were not dependent upon alteration of the total protein content of the circulating plasma. The decrease in specific gravity of the plasma following the intravenous injection of hypertonic solutions of glucose takes place with surprising rapidity, the maximum reduction being present a few minutes after the infusion is finished. The dilution of the plasma which is indicated by the de. crease in specific gravity corresponds approximately to the increase in plasma volume of the circulating blood which Smith demonstrated in dogs under conditions similar to ours. The return of the specific gravity to its original level occurs with the removal of the excess fluid from the blood. 
It is a fact that the organism quickly restores to a normal level a lowered concentration of protein in the plasma which has been artificially induced. This is the situation following large hemorrhages. If, on the other hand, deficiency of protein in the plasma of the blood is a manifestation of disease, as is the case in nephritis with edema, the low level is maintained over long periods of time (1); we are at: present without measures of increasing the protein content of the plasma within a short time. The attempts to increase the specific gravity of plasma independently of its protein content by intravenous injections of gum acacia were only partially successful, since the addition of relatively large amounts of it to the circulating blood resulted in only slight rises in the specific gravity.

\section{SUMMARY}

1. The anticoagulant used has an effect on the specific gravity of the plasma. If data are to be compared with those published by Moore and Van Slyke, heparin must in consequence be used.

2. It has been demonstrated that the specific gravity of the plasma and, on the basis of Moore and Van Slyke's observations, the plasma proteins of normal individuals show remarkable constancy for short periods (days) provided the samples of blood are taken at the same time each day.

3. In patients suffering from heart disease who were in water balance the maximum and minimum daily variations in the specific gravity were 0.0004 and 0 respectively.

4. In two normal individuals the variations were 0.0015 and 0.0011 over a period of 14 months. There was corresponding variation in the protein content of the plasma.

5. The specific gravity of the plasma of a normal individual varied 0.0007 in the course of a day.

6. The protein content and the specific gravity of the plasma of arterial blood is less than of venous blood.

7. The injection intravenously in dogs of normal salt solution resulted in decrease in the specific gravity of the plasma of the blood. The administration of water $1000 \mathrm{cc}$. by mouth to human beings decreased the specific gravity of the plasma, however, only slightly. 
8. During "concentration tests" two patients exhibited increases $(0.0013)$ in the specific gravity of the plasma of the blood.

9. Hemorrhage was followed by decrease in specific gravity of the plasma, and a corresponding decrease in the plasma protein concentration. Return to the initial level occurred 4 days after bleeding.

10. The intravenous injection of hypertonic solutions of glucose resulted in decrease in the specific gravity of the plasma.

11. The injection of gum acacia in glucose solution increased the specific gravity of the plasma slightly, but the volume of fluid injected and the dilution resulting from the presence of hypertonic glucose solution decreased the protein concentration.

12. The specific gravity and the protein content of the plasma of patients suffering from cardiac disease are within the range found in normal individuals.

13. In those cardiac patients exhibiting edema as well as in those in whom this sign is not present, there is a linear relationship between the specific gravity and the total protein content of the plasma which is expressed by the formula of Moore and Van Slyke.

\section{CONCLUSIONS}

1. The specific gravity of the plasma and parallel with it the plasma proteins show only small fluctuations in normal individuals.

2. Bleeding, intravenous injection of normal salt solution, the intravenous injection of hypertonic glucose solution, and to a much less extent, the ingestion of water may bring about dilution of the plasma and in consequence alterations in the normal specific gravity and in the concentration of the plasma proteins; on the other hand, withholding fluid and ingestion of a dry diet may raise the specific gravity and the concentration of the proteins. The ingestion of fat also decreases the specific gravity of the plasma.

3. The specific gravity and protein content of the plasma of patients suffering from cardiac disease irrespective of the presence of edema was greater than that associated with edema in nephritic patients.

4. The protein content of the plasma of cardiac patients may be calculated from the observed value of the specific gravity of the plasma by applying the formula published by Moore and Van Slyke (1) for use in normal individuals and patients suffering from Bright's disease. 


\section{BIBLIOGRAPHY}

1. Moore, N. S., and Van Slyke, D. D., J. Clin. Invest., 1930, viii, 337. The Relationships Between Plasma Specific Gravity, Plasma Protein Content and Edema in Nephritis.

2. Linder, G. C., Lundsgaard, C., and Van Slyke, D. D., J. Exp. Med., 1924, xxxix, 887. The Concentration of the Plasma Proteins in Nephritis.

3. Salvesen, H. A., Acta Med. Scandin., 1926-27, lxv, 147. Plasma Proteins in Normal Individuals.

4. Epstein, A. A., Am. J. Med. Sci., 1917, cliv, 638. Concerning the Causation of Edema in Chronic Parenchymatous Nephritis. A Method for Its Alleviation.

5. Salvesen, H. A., Acta Med. Scandin., 1929, lxxii, 113. Variations in the Plasma Proteins in Non-renal Conditions.

6. Butterfield, E. E., Erdwurm, F., and Braddock, W. H., Am. J. Med. Sci., 1916, cli, 63. The Differentiation of Nephropathies, Cardiopathies and Allied Conditions.

7. Greene, C. H., and Rowntree, L. G., Proc. Am. Physiol. Soc., Am. J. Physiol., 1924, lxviii, 111. Changes in the Concentration of the Blood Following the Administration of Excessive Quantities of Water.

8. Lee, F. W., Carrier, E. B., and Whipple, G. H., Am. J. Physiol., 1922, Ixi, 149. II. Simultaneous Determinations of Plasma and Hemoglobin Volumes. Influence of Fluids by Mouth and Vigorous Exercise.

9. Cipriani, C., and Moracchini, R., Minerva Med., 1925, v, 261. Comportamento del Siero di Sangue e Della Diuresi Nell'ortostatismo.

10. Thompson, W. O., Thompson, P. K., and Dailey, M. E., J. Clin. Invest., 1928, v, 573. The Effect of Posture upon the Composition and Volume of the Blood in Man.

11. Goevaerts, P., Bull. Acad. royal de méd. de Belg., 1924, iv, 161. Recherches Cliniques sur le Rôle de la Pression Osmotique des Protéines du Sang dans la Pathogénie des Oedèmes et de l'Hypertension Arterielle.

12. Howe, P. E., J. Biol. Chem., 1921, xlix, 109. The Determination of Proteins in Blood-A Micro Method.

13. Van Slyke, D. D., J. Biol. Chem., 1927, lxxi, 235. Gasometric Micro-Kjeldahl Determination of Nitrogen.

14. Kerr, W. J., Hurwitz, S. H., and Whipple, G. H., Am. J. Physiol., 1918-19, xlvii, 356. Regeneration of Blood Serum Proteins. I. Influence of Fasting upon Curve of Protein Regeneration Following Plasma Depletion.

15. Leiter, L., and McLean, F. C., Proc. Am. Soc. Clin. Invest., J. Clin. Invest., 1929, vii, 493. Experimental Edema.

16. Isaac, S., Therap. Halbmonatshefts, 1921, xxxv, 698. Utber Beeinflussung der Herztätigkeit und der Diurese durch intravenöse Traubenzuckerinfusionen. 
17. Büdingen, T., Schweiz. Med. Wchnschr., 1923, iv, 395. Stoffwechselbehandlung des Herzens (Kardiotrophotherapie) mittelst Einläufen hypertonischer Traubenzuckerlösungen in die Blutbahn.

18. Smith, H. P., Bull. Johns Hopkins Hosp., 1925, xxxvii, 177. Intravenous Injections of Fluid and Repeated Blood Volume Determination.

19. Stewart, H. J., and McIntosh, J. F., J. Clin. Invest., 1928, vi, 325. The Function of the Kidneys in Patients Suffering from Chronic Cardiac Disease Without Signs of Heart Failure.

20. Strasser, U., Wien. Arch. f. inn. Med., 1930, xix, 451. Die Pyknometrie des Blutserums im Dienste der Klinik.

21. Gage, S. H., and Fish, P. A., Am. J. Anat., 1924, xxxiv, 1. Fat Digestion, Absorption, and Assimilation in Man and Animals as Determined by the Dark-field Microscope, and a Fat Soluble Dye. 